\title{
Measurement of methane flux in the selected area of the Polish Outer Carpathians - preliminary research
}

\author{
Anna Twaróg, Piotr Guzy, Henryk Sechman \\ AGH University of Science and Technology, Faculty of Geology Geophysics and Environmental Protection, \\ Department of Fossil Fuels; al. A. Mickiewicza 30,30-059 Krakow, Poland; e-mail:piotrgu@agh.edu.pl \\ (C) 2016 Authors. This is an open access publication, which can be used, distributed and reproduced in any medium according \\ to the Creative Commons CC-BY 4.0 License requiring that the original work has been properly cited.
}

Methane emissions associated with the hydrocarbon-generation process occurring in sedimentary basins are considered to be one of two types of geologic sources of methane emissions to the atmosphere. Current methane emissions releasing from geological sources amount 45-60 $\mathrm{Tg} \mathrm{CH}_{4} \mathrm{yr}^{-1}$. The measured values of flux migrating from soil into the atmosphere are influenced by a series of factors, e.g. porosity and permeability of overlying layers, occurrence of cracks and faults, atmospheric pressure, seasonal temperature fluctuations and presence of methanotrophic bacteria. The latter, as a result of methane consumption, may trigger negative flux values (Etiope 2015). Previously, the methane emission measurements in the Polish Outer Carpathians were carried out with a method of static chambers (Sechman \& Dzieniewicz 2009). The studies presented in the paper consisted in initial methane emission measurements by flux meter. Their purpose was to examine distribution of methane fluxes on the land surface, as well as change in emission along with depth, omitting the 'screening' near-surface zone. The studies were carried out in a small area of the Carpathian petroleum oil region, nearby Rymanów, between October and December 2015.

Measurement of the methane fluxes were performed with application of a portable flux meter (West System 2012). The device performs one measurement per second on average, recording concentration changes in time $(\mathrm{ppm} / \mathrm{s})$. Average measurement time was 360 seconds. When a high methane concentration was registered, gas samples were collected from the accumulation chamber and directed to a detailed chromatographic analysis (field sampling and analytical procedure - see Sechman \& Dzieniewicz 2009).

There were 137 measurements taken on 87 stands in total, recording emission from the land surface, and emission with application of 1-m deep holes - in order to omit the "screening" near-surface zone (Sechman \& Dzieniewicz 2009). The emission was recorded along the 1000$\mathrm{m}$ long profile, where samples of soil gas were collected previously, and around the drill holes covered with soil. Furthermore, during the process of drilling 4 boreholes, there were $\mathrm{CH}_{4}$ test emission measurements taken examining change in methane flux with depth (to $10 \mathrm{~m}$ ). In case of the KB-7 borehole, measurements were taken 1 and 22 days after the drilling.

The natural emission was recorded on 70 measuring stations. The flux was identified only in $30 \%$ of the performed measurements. Negative emission was predominant within the examined area (68\% of all measurements), with an average value of $-3.8 \mathrm{mg} \cdot \mathrm{m}^{-2} \cdot \mathrm{d}^{-1}$. Average value of the positive flux reached $3 \mathrm{mg} \cdot \mathrm{m}^{-2} \cdot \mathrm{d}^{-1}$. Range of the measured flux values is comprised within the scope from $-5.2 \mathrm{mg} \cdot \mathrm{m}^{-2} \cdot \mathrm{d}^{-1}$ to $14.9 \mathrm{mg} \cdot \mathrm{m}^{-2} \cdot \mathrm{d}^{-1}$. Emission measurements with the additional holes were carried out at 37 positions. Fluxes with positive values were identified in 6 of them, while the negative values were recorded in 4 . Range of the measured 
flux values with the additional hole was from $-6.4 \mathrm{mg} \cdot \mathrm{m}^{-2} \cdot \mathrm{d}^{-1}$ to $2 \mathrm{mg} \cdot \mathrm{m}^{-2} \cdot \mathrm{d}^{-1}$; average negative and positive flux values are as follows, respectively: $-2.3 \mathrm{mg} \cdot \mathrm{m}^{-2} \cdot \mathrm{d}^{-1}$ and $1.3 \mathrm{mg} \cdot \mathrm{m}^{-2} \cdot \mathrm{d}^{-1}$. Within the examined area, methane emission from the land surface, and to the depth of $1 \mathrm{~m}$, was identified only in $30 \%$ of measurements. The measurements are characterized by low values, from $-6.4 \mathrm{mg} \cdot \mathrm{m}^{-2} \cdot \mathrm{d}^{-1}$ to $14.9 \mathrm{mg} \cdot \mathrm{m}^{-2} \cdot \mathrm{d}^{-1}$.

Results of test emission measurements recorded in subsequently drilled depth intervals, performed for 4 drilling boreholes. For the KB-6, KB-7, KB- 8 and KB-10 boreholes, average values of methane emission from subsequent depth intervals were as follows, respectively: 49.2, 68.6, 3.5 and $1.5 \mathrm{mg} \cdot \mathrm{m}^{-2} \cdot \mathrm{d}^{-1}$. These results are higher than values of natural emission measured on the land surface or with application of holes to $1 \mathrm{~m}$.

The highest emission values were recorded for the KB-7 borehole. A detailed distribution of $\mathrm{CH}_{4}$ flux values was correlated with a lithology and molecular composition of gas collected from the accumulation chamber in three depth intervals $(3.5 \mathrm{~m}, 5.5 \mathrm{~m}$ and $10 \mathrm{~m})$. Results of the gas molecular analysis prove that the source of methane emission is characterized by both microbial and endogenous origin. It is assumed that occurrence of components heavier than methane in the samples, arises from their depth origin (Saunders et al. 1991). An increase of methane concentration in intervals related to occurrence of shales - may suggest its recent origin. It also needs to be noticed that $\mathrm{C}_{1} / \mathrm{C}_{2}$ ratio values (from 207 to 807 ) increase along with depth, what may prove prevailing share of microbial methane. When 24 hours passed after drilling the KB-7 borehole, the emission value dropped to $0.6 \mathrm{mg} \cdot \mathrm{m}^{-2} \cdot \mathrm{d}^{-1}$, and after about three weeks, during an hourly emission measurement, a positive flux of $0.1 \mathrm{mg} \cdot \mathrm{m}^{-2} \cdot \mathrm{d}^{-1}$ was observed in time $0-470$ second and a negative flux of $-0.05 \mathrm{mg} \cdot \mathrm{m}^{-2} \cdot \mathrm{d}^{-1}$ was observed in time 480-2660 second. Furthermore, small concentrations of ethane $(0.006 \mathrm{ppm})$ and ethylene $(0.005 \mathrm{ppm})$ were identified in gas sample collected after 22 days.

The emissions study conducted in the Rymanów area (Outer Carpathians) indicates the mixed source of methane. In order to determine the detailed methane source, it would be necessary to perform an analysis of the carbon isotopic composition in the samples taken. The low emission values measured on the land surface results from the fact that the emissions were suppressed by the sealing overburden layer. The measurements taken 1 day and then 22 days after drilling in the KB-7 stabilized borehole, show a decline in emissions value. This may result from an insignificant inflow of hydrocarbons from the depth, bacterial oxidation of these hydrocarbons, and from the influx of air to the borehole.

Financial support of this work comes from the research program National Centre for Research and Development Blue Gas (BG2/ShaleCarp/14).

\section{REFERENCES}

Etiope G., 2015. Natural Gas Seepage. The Earth's Hydrocarbon Degassing. Springer, Switzerland.

Saunders D.F., Burson K.R. \& Thompson C.K., 1991. Observed relation of soil magnetic susceptibility and soil gas hydrocarbon analyses to subsurface petroleum accumulations. AAPG Bulletin, 77, 1219-1240.

Sechman H. \& Dzieniewicz M., 2009. Pomiary emisji metanu w wybranych rejonach polskich Karpat Zewnętrznych. Geologia, 35, 4/1, 129-153 [with English abstract].

West Systems, 2012. Portable diffuse flux meter with LI-COR $\mathrm{CO}_{2}$ detector. Handbook. [on-line:] http://www.westsystems.com/doc/Handbook_Portable_8.2.pdf [access: January 2016]. 